F. Reprod. Fert. (1969) 19, 121-131

\title{
MITOTIC ACTIVITY IN THE ADENOHYPOPHYSIS OF PREGNANT AND LACTATING RABBITS
}

\author{
M. ALLANSON, G. L. FOSTER ANd E. GAMERON \\ Department of Biology, St. Mary's Hospital Medical School, London
}

(Received 1st July 1968, revised 8th November 1968)

\begin{abstract}
Summary. The rate of mitosis in the adenohypophysis of colchicinetreated female rabbits has been studied in five unmated, non-parous does (controls), nineteen pregnant primiparae, seventeen suckling and five non-suckling post partum primiparae. Data are presented showing that, although the average mitotic rate was higher in Week 4 of pregnancy $\left(4 \cdot 1 \mathrm{mitoses} / \mathrm{mm}^{2}\right)$ than in the unmated animals $\left(1 \cdot 7 \mathrm{mitoses} / \mathrm{mm}^{2}\right)$, only in Weeks 1 and 2 of lactation $\left(8.5 \mathrm{mitoses} / \mathrm{mm}^{2}\right.$ and 12.0 mitoses/ $\mathrm{mm}^{2}$, respectively) was the increase in mitotic rate statistically significant.

Five per cent of all the mitotic figures examined occurred in mucoid cells, $23 \%$ in non-granular cells, and $72 \%$ in acidophil cells (prolactin cells and somatotrophs). The majority of mitoses was found in prolactin cells $(74 \%)$ during pregnancy and in somatotrophs $(64 \%)$ in late lactation; in Weeks 1 and 2 of lactation, when cell proliferation was most rapid, most of the dividing cells were unidentifiable owing to lack of granules, so that at this period the mitotic rate of these two acidophil cell types could not be determined.

Fluctuations in the mitotic rate in the epithelial cells of the duodenum of the animals did not appear to be correlated with the stages of pregnancy or of lactation.
\end{abstract}

\section{INTRODUCTION}

Considerable changes in the acidophil cells of the adenohypophysis during pregnancy and lactation have been reported for several mammalian species. The cells appear to increase in number and granular content during pregnancy and to undergo massive loss of granules in early lactation (Allanson \& Parkes, 1966). In some species these modifications have been ascribed to heightened activity of the cell type believed to secrete prolactin (Herlant, 1964). In the rabbit, beside the stimulation of the prolactin cells, parallel though less marked changes have been described in the cell type usually identified with somatotrophin production (Gepts, 1954; Allanson, Gameron \& Foster, 1966).

In the present study, we have investigated the mitotic activity in the pituitaries of rabbits experiencing their first pregnancy or lactation so as to find out how far the apparent fluctuations in the cell population are due to variation in the rate of cell division. We have also attempted to analyse the contribution 
made by some of the types of cells to the overall mitotic rate. Colchicine was used to arrest mitoses at metaphase because the numbers of dividing cells encountered in previous studies of the rabbit gland were too few for such an analysis. We chose colchicine rather than an autoradiographical technique, although the latter has considerable advantages (Hunt \& Hunt, 1966), as it can be followed by a wider range of staining methods. Some authorities consider that colchicine should be avoided because of its toxicity and because at certain dose levels it stimulates or depresses mitotic activity (Carter, 1953). On balance, however, the evidence indicates that, if a minimal dose sufficient to cause mitotic arrest is given for a period of not more than $5 \mathrm{hr}$, the counts obtained are a dependable measure of normal activity and can be used for comparative purposes (Leblond \& Walker, 1956; Altmann \& Enesco, 1967).

Previous studies on mitosis in the mammalian hypophysis have been confined largely to the rat and mouse. The results are not always in accord in the two species. According to Hunt (1943), mitoses are more frequent in the glands of young mature rats than in older ones; they are less frequent in the $9 \mathrm{hr}$ after midnight than at other times of the day. Kerr (1943) reported two maxima during the mouse cycle, one in late di-oestrus and pro-oestrus, the other in late oestrus. In the rat, Hunt \& Hunt (1966) found the mitotic rate was higher from 12 to $24 \mathrm{hr}$ after ovulation than in other phases of the cycle. The pattern of mitotic activity during pregnancy also differs in the two species (Ladman, 1954; Hunt, 1949). Most of the divisions observed in the above investigations were in acidophil and chromophobe cells, but Pomerat (1941) recorded a high mitotic rate in the basiphil cells of rats following castration.

\section{MATERIALS AND METHODS}

Forty-six non-parous Dutch rabbits about 6 months old were used, of which five unmated animals served as controls; nineteen were killed at various times during their first pregnancy and seventeen at various times during their first lactation. Five post partum animals lost their litters within a few hours of birth and were classed as 'non-suckling'. The earlier stages in pregnancy were confirmed by examination of the ovaries for evidence of ovulation.

The animals were given a single dose of colchicine $(5 \mathrm{mg} / \mathrm{kg})$ through the ear vein at 10.00 hours and were killed with ether $5 \mathrm{hr}$ later.

The pituitaries were fixed by perfusion with Baker's formol-calcium-cadmium fluid as described by Allanson, Foster \& Menzies (1959), and were sectioned serially at $5 \mu$ in the horizontal plane.

The following staining methods were used on representative series of sections from all pituitaries.

1. Periodic acid/orange $G$ for differentiation of the acidophil and mucoid (basiphil) cell classes.

2 (a) A modification of Cleveland and Wolfe's trichrome method (Allanson et al., 1966) and/or (b) Brookes's trichrome stain (Brookes, 1968) for differentiation of two types of the acidophil cell class. Cells stained orange after these techniques were classed as somatotrophs: those stained with erythrosin after (a) or carmoisine after (b) were classed as prolactin cells. 
Celestin blue and haemalum were used for the nuclei in all three staining methods.

In all animals, three non-contiguous PAS/orange $G$ stained sections from each of three levels of the pars distalis were scanned under an oil immersion lens, making a total of nine sections for each rabbit. The levels selected were (a) near the ventral surface, (b) approximately median, and (c) near the dorsal surface. All metaphase stages were counted in each section. Nuclei in the earlier stages of division, before the disappearance of the nuclear membrane, are more difficult to recognize and were not included. The means of the three counts obtained from each of levels (a), (b) and (c) were used to arrive at the 'mitotic rate' in the following way. It was necessary to express the number of mitotic figures in terms of a fixed amount of pituitary tissue, because of the varying cross-sectional area of the pars distalis both as between different glands and between the three levels of the same gland. Representative sections from the levels studied were projected at a magnification of 35 diameters on to white cardboard of standard thickness; the image of the pars distalis (but not of the pars intermedia) was outlined, cut out and weighed. A similar cut-out of the image of a square millimetre of a graticule projected at the same magnifica tion was weighed, and the weights of the scanned sections then converted to square millimetres. Mitotic activity was expressed as the number of mitoses $/ \mathrm{mm} 2$ of section. The area examined for mitotic figures varied with the size of the gland from 28 to $53 \mathrm{~mm} 2$ per pituitary.

In order to determine the frequency of mitosis in the two types of acidophil cells, sections stained by methods 2(a) and 2(b) above were scanned under an oil immersion lens and all dividing cells counted and classified on their staining reactions and morphological features. Sections were selected from several levels of the glands.

So as to check that the colchicine had been effective and to study the rate of mitosis in a tissue other than the pars distalis, a piece of duodenum proximal to the pylorus, approximately $1 \mathrm{~cm}$ in length, was obtained from each animal, and fixed in the same way as the pituitary. The duodenum was chosen because of its known high mitotic activity. Sections were cut at $5 \mu$ in the longitudinal plane and stained with hacmatoxylin and eosin. The mitotic figurns werc counted in the epithelial cells of the crypts in fifteen successive microscope fields of each of three non-contiguous sections (a total of forty-five fields in each animal) and the results expressed as an average.

\section{RESULTS}

Pregnant and lactating animals were grouped together for successive 8-day intervals making, with the unmated animals, nine groups in all. The means of the mitotic rates of the nine groups, and the proportions of the three classes of cells (acidophil, mucoid and non-granular or chromophobe) in the total mitotic count for each group, are listed in Table 1. Mitotic rates for the individual animals, together with the mean values for the groups, are shown diagrammatically in Text-fig. 1.

The values for the individual pituitaries show a fairly wide scatter in all 
groups but it appears that the rate of cell proliferation rose slowly in late pregnancy, more rapidly soon after parturition, and remained at a high level in the first 2 weeks of lactation: the mean mitotic rates obtained were 1.7 mitoses $/ \mathrm{mm}^{2}$ in the unmated animals, 4.1 mitoses $/ \mathrm{mm}^{2}$ in Week 4 of pregnancy, and 8.5 and 12 mitoses $/ \mathrm{mm}^{2}$, respectively, for Weeks 1 and 2 of lactation (Table 1). The difference between the mean of the combined values for the first 2 weeks of lactation and that for the whole of pregnancy was found to be statistically significant (Table 2): the difference between the mean of the combined values for the first and second halves of pregnancy $\left(1.6 \mathrm{mitoses} / \mathrm{mm}^{2}\right.$ and $3 \cdot 1$ mitoses $/ \mathrm{mm}^{2}$, respectively) was not so significant $(0 \cdot 2>P>0 \cdot 1)$. The

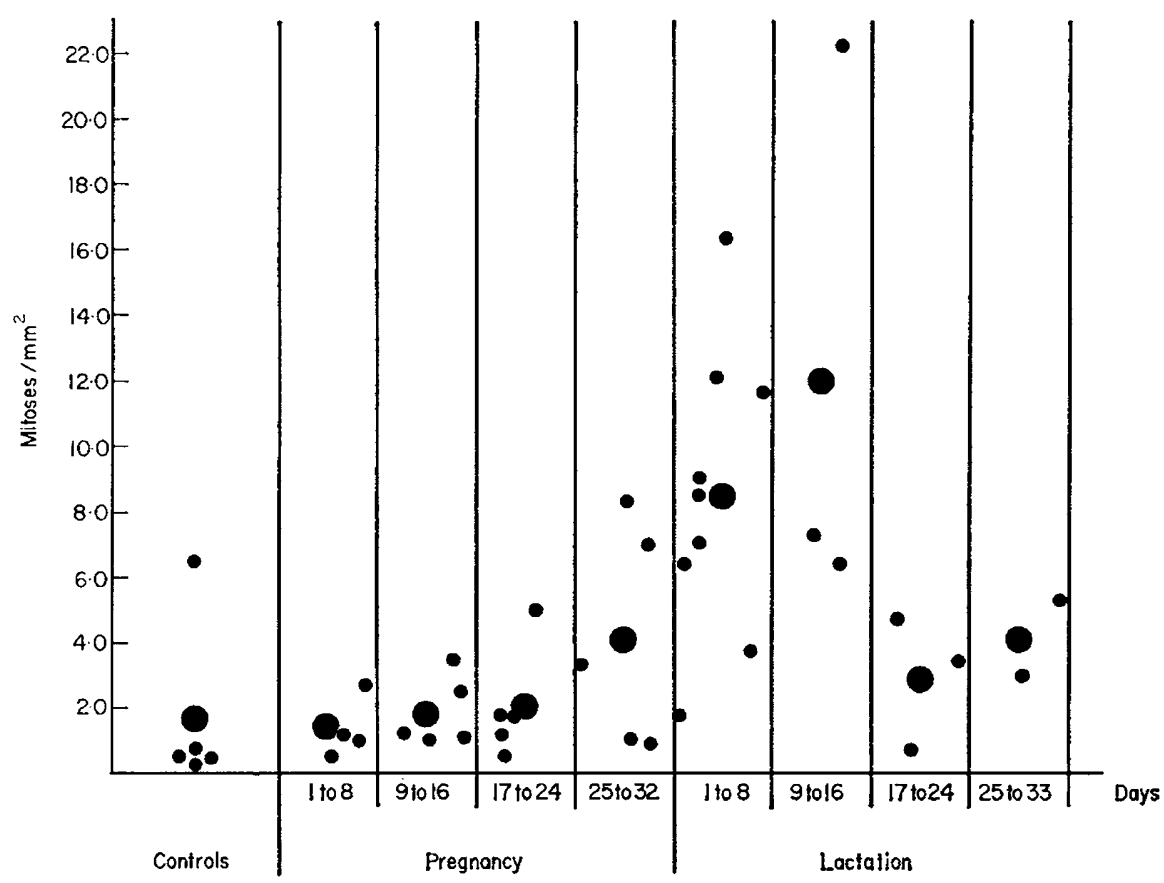

TExT-FIG. 1. The number of mitoses per $\mathrm{mm}^{2}$ in the adenohypophyses of groups of control, pregnant and lactating rabbits. The diagram shows the range of values for the individual animals within the groups (small symbol) and the mean values for the groups (large symbol.)

mitotic rate may slacken in Weeks 3 and 4 of lactation (mean mitotic rates of 2.9 and 4.1 mitoses $/ \mathrm{mm}^{2}$, respectively) but the number of animals examined (five) was too low to draw valid conclusions (Table 1). Mitotic activity appeared to be much lower in non-suckling than in suckling does: a mean rate of 11.4 mitoses $/ \mathrm{mm}^{2}$ was recorded for three animals killed in the 1st week, and of 0.4 mitoses $/ \mathrm{mm}^{2}$ for two animals killed in the 3rd week post partum, but unfortunately the number of examples is too small for statistical analysis.

In order to determine whether cell proliferation was widespread or localized within the pars distalis, all mitoses were plotted on outline drawings of sections taken at four to six levels in several representative pituitaries. Mitotic activity appeared to be randomly distributed except that dividing cells were very scarce in the zona tuberalis. The zona accounts for approximately a quarter 


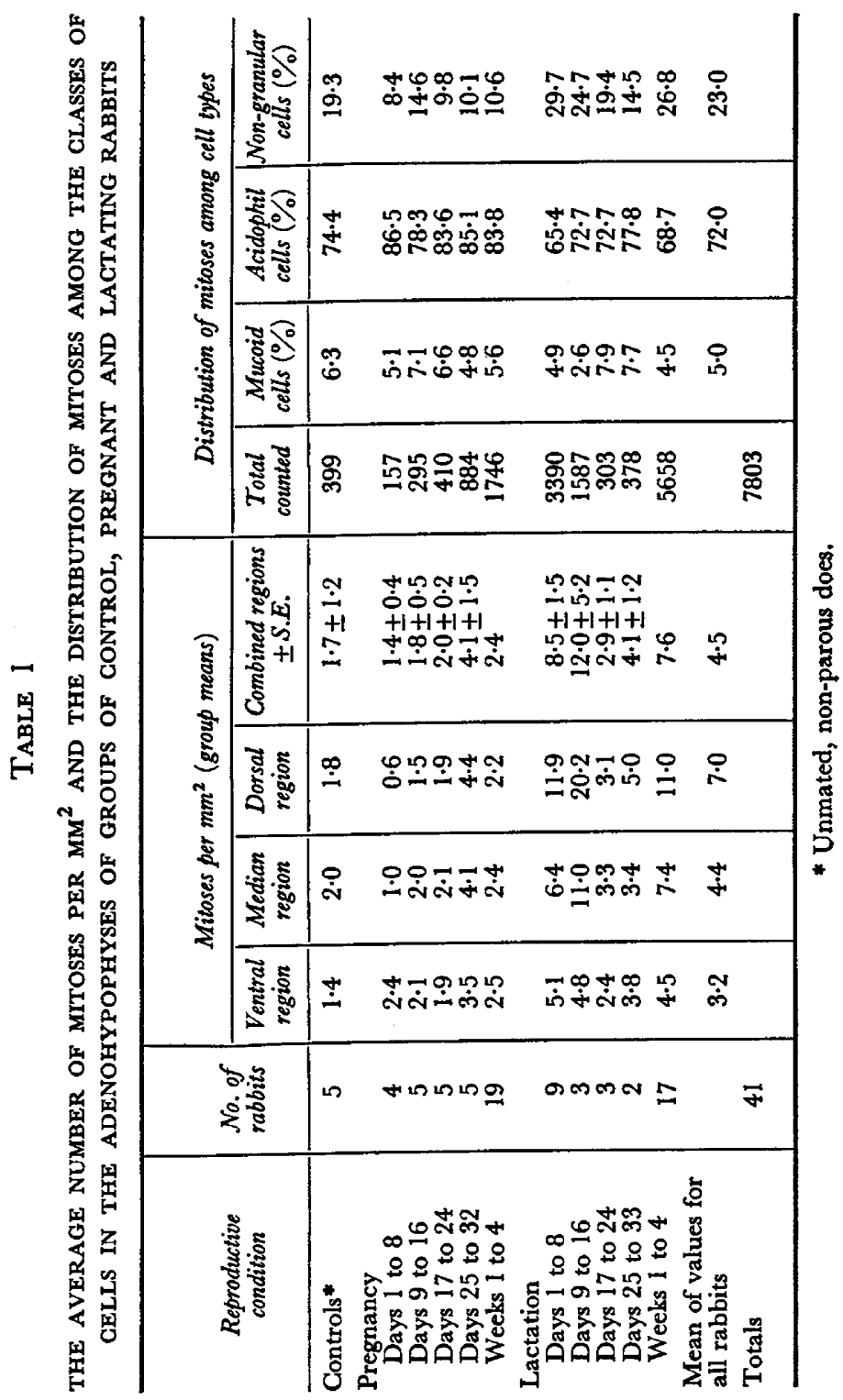


to a third of the area of a horizontal section in the ventral and median regions of a rabbit's pituitary, where it merges with the pars distalis proper (Dawson, 1937). Dorsally, the zona separates from the pars distalis and fuses with the pars tuberalis: it was not, therefore, included in the area scanned for mitoses. Accordingly, the number of mitoses per unit area for the dorsal region is artificially high compared with those for the other two regions.

In addition, the mitotic values for each of the ventral, median and dorsal levels of the gland were studied separately (Table 1). The incidence of dividing cells at the several levels did not appear to follow any pattern common to control, pregnant and lactating animals, but the distribution of mitotic activity in the lactating animals differed from that in the other two groups. While it is evident that cell proliferation had accelerated at all three levels of the gland in early lactation, the figures indicate that the acceleration had been greater in

TABLE 2

GOMPARISON OF MITOTIC AGTIVITY THROUGHOUT PREGNANCY WITH THAT DURING EARLY LACTATION IN (a) THE PARS DISTALIS AND (b) THE INTESTINAL EPITHELIUM

\begin{tabular}{|c|c|c|c|}
\hline & $\begin{array}{c}\text { Pregnancy } \\
\text { Weeks } 1 \text { to } 4\end{array}$ & $\begin{array}{l}\text { Lactation } \\
\text { Weeks } 1 \text { and } 2\end{array}$ & $P$ \\
\hline $\begin{array}{l}\text { Mitotic activity in adenohypophysis } \\
\text { ventral region } \\
\text { median region } \\
\text { dorsal region } \\
\text { combined regions }\end{array}$ & $\begin{array}{l}2.5 \mathrm{mitoses} / \mathrm{mm}^{2} \\
2.4 \mathrm{mitoses} / \mathrm{mm}^{2} \\
2.2 \mathrm{mitoses} / \mathrm{mm}^{2} \\
2.4 \mathrm{mitoses} / \mathrm{mm}^{2}\end{array}$ & $\begin{array}{r}5 \cdot 1 \text { mitoses } / \mathrm{mm}^{2} \\
9 \cdot 1 \text { mitoses } / \mathrm{mm}^{2} \\
14.3 \text { mitoses } / \mathrm{mm}^{2} \\
9 \cdot 4 \text { mitoses } / \mathrm{mm}^{2}\end{array}$ & $\begin{array}{l}0.01>P>0.001 \\
0 \cdot 001>P>0.0001 \\
0 \cdot 001>P>0.0001 \\
0.01>P>0.001\end{array}$ \\
\hline $\begin{array}{l}\text { Proportion of mitoses in } \\
\text { mucoid cells } \\
\text { acidophil cells } \\
\text { non-granular cells }\end{array}$ & $\begin{array}{l}5.6 \% \\
83.8 \% \\
10.6 \%\end{array}$ & $\begin{array}{l}4 \cdot 1 \% \\
67 \cdot 7 \% \\
28 \cdot 2 \%\end{array}$ & $\begin{array}{l}0.2>P>0.1 \\
0.01 \\
0.01>P>0.001\end{array}$ \\
\hline $\begin{array}{l}\text { Mitotic activity in intestinal } \\
\text { epithelium }\end{array}$ & 6.3 mitoses/field & 7.5 mitoses/field & $0.4>P>0.3$ \\
\hline
\end{tabular}

the dorsal and median regions than in the ventral so that a dorso-ventral gradient in mitotic activity was apparent. The difference between the mean of the combined values for Weeks 1 and 2 of lactation and those for the whole of pregnancy was found to be statistically significant in each of the three regions (Table 2).

Of the total of 7803 dividing cells examined, $72 \%$ contained acidophil granules, $5 \%$ contained mucoid (PAS-positive) material, and $23 \%$ lacked visible granules and were not therefore identifiable (Table 1). The dividing acidophil and mucoid cells were in all stages of granulation, from lightly to heavily charged. The majority of mitoses was found in acidophil cells in all groups of animals: in the unmated controls they made up $74.4 \%$, mucoid cells $6.3 \%$, and non-granular cells $19.3 \%$ of the total. In pregnancy, the proportion of acidophil cells rose from 78.3 to $86.5 \%$ of the total while that of the nongranular cells fell. In Week 1 of lactation, when there is rapid release of secretion and little accumulation of cytoplasmic granules, the proportion of dividing acidophils fell to $65.4 \%$ while that of non-granular cells more than doubled. Moreover, the majority of the acidophils in mitosis at this period $(77 \%)$ 
contained very few granules whereas during pregnancy the greater number $(67 \%)$ were heavily granulated. As the overall mitotic rate slackened later in lactation, there was a return towards the condition found in control animals. The number of mitoses observed in mucoid cells was very small in all animal groups. The percentage of dividing mucoid cells in the total mitotic count was slightly higher in mid-pregnancy than in the controls; it fell before parturition and remained low during the first 2 weeks of lactation. A statistical significance was demonstrated for the difference between the percentage figures in the first 2 weeks of lactation and the 4 weeks of pregnancy for both the dividing acido phils and the non-granular cells: the difference in the percentages for the mucoid cells, however, was not statistically significant (Table 2).

The incidence of mitosis in the two types of acidophil cells was studied in three unmated, thirteen pregnant and twelve lactating animals. The pregnant

Table 3

\begin{abstract}
the proportions of somatotrophs and of prolactin cells in the total of dividing acidophil cells in groups of control, pregnant and lactating rabbits
\end{abstract}

$\begin{array}{lcccc}\begin{array}{c}\text { Reproductive } \\ \text { condition }\end{array} & \begin{array}{c}\text { No. of } \\ \text { rabbits }\end{array} & \text { No. counted } & \begin{array}{c}\text { Acidophil cells } \\ \text { Somatotrophs } \\ (\%)\end{array} & \begin{array}{r}\text { Prolactin cells } \\ (\%)\end{array} \\ \text { Controls* } & & 283 & 97-9 & 2-1 \\ \text { Pregnancy } & & & & \\ \text { Days 1 to 16 } & 4 & 224 & 80 & 92-0 \\ \text { Days 17 to 32 } & 9 & 1150 & 30-0 & 70-0 \\ \text { Days 1 to 32 } & 13 & 1374 & 26-4 & 73-6 \\ \text { Lactation } & 8 & 795 & 53-4 & 46-6 \\ \text { Days 1 to 16 } & 4 & 587 & 64-4 & 35-6 \\ \text { Days 17 to 33 } & 12 & 1382 & 58-8 & 41-2 \\ \text { Days 1 to 33 } & 28 & 3039 & & \\ \text { Totals } & & & & \\ & * & & \end{array}$

and lactating animals were grouped togethor for successive fortnightly intervals. In the controls, the majority of divisions occurred in somatotroph cells: the number encountered in prolactin cells was negligible (Table 3). Throughout pregnancy, mitoses were more frequent in prolactin cells than in somatotrophs. In the first 2 weeks of lactation, mitoses appeared to be almost equally distributed between the two cell types, but it should be noted that 25 to $30 \%$ of all divisions counted in this period were found in non-granular cells, and most of these were probably degranulated acidophil cells. The actual distribution of mitoses between the prolactin and somatotroph cells may therefore be different from that recorded. In the few pituitaries obtained in Weeks 3 and 4 of lactation, there was a marked decrease in mitotic activity in the prolactin cells and a rise in that of the somatotrophs; the proportion of dividing non-granular cells had fallen to near the control level.

The mitotic frequencies in the duodenum are represented diagrammatically in Text-fig. 2 where the results from the pregnant and lactating animals have 
been grouped together in successive 8-day intervals for comparison with Textfig. 1. Fluctuations in the mitotic rate in the epithelial cells of the crypts, unlike those in the adenohypophysis, do not appear to be correlated with pregnancy or lactation and were not statistically significant $(0.4>P>0.3)$.

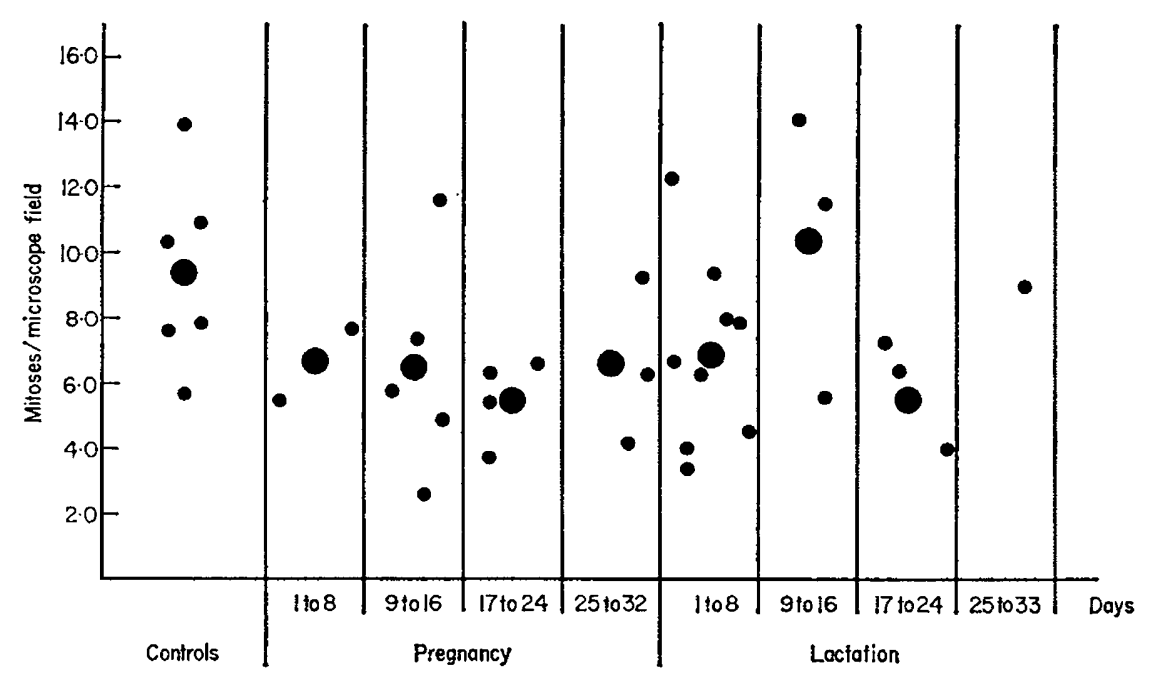

TEXT-FIG. 2. The number of mitoses in a standard area of duodenal epithelium in groups of control, pregnant and lactating rabbits. The diagram shows the range of values for the individual animals within the groups (small symbol) and the mean values for the groups (large symbol).

\section{DISCUSSION}

The pattern of mitotic activity in the rabbit pituitary during pregnancy and lactation differs in some particulars from that in the mouse (Ladman, 1954) and the rat (Hunt, 1949). In the mouse, mitotic activity decreases between the 6 th and 9th days of pregnancy and thereafter rises steadily until parturition. In the rat, activity rises in the first 3 days of pregnancy and then declines to a level comparable with that in di-oestrus; during lactation, cell production is rapid for the first 3 days and then falls to the di-oestrous level. Racadot (1955) confirmed the striking upsurge in cell proliferation after parturition in the rat and he reported a similar, though smaller, rise in the guinea-pig. In the present study, no statistically significant rise in mitotic activity was discernible during pregnancy in the primiparous rabbit, but a significant acceleration was found within $24 \mathrm{hr}$ of parturition. The mitotic rate remained high during the first 2 weeks of lactation and then appeared to diminish.

It is surprising that the mitotic activity of the mucoid cells remained consistently low in all stages examined because considerable changes in the number of the granular stages of these cells have been reported in the pregnant and lactating rabbit (Gameron, Foster \& Allanson, 1966). However, our findings are in agreement with reports by other workers. Ladman (1954) noted a uniform rate of division of the basiphil (mucoid) cells throughout pregnancy in the 
mouse; few mitoses of basiphil cells were observed during the oestrous cycle of the mouse by Kerr (1943), and none during the cycle of the rat by Hunt \& Hunt (1966). The latter authors, moreover, used an autoradiographic technique which reveals the interphase events preceding prophase of the mitotic cycle that are not seen by other methods. It is possible that the reserve of mucoid cells is so abundant that a large part of any observed numerical increase has been produced by the transformation of inactive to active stages whereas most of an increase in the acidophil cell population is due to cell proliferation.

The fluctuations in the relative numbers of prolactin cells and somatotrophs among the total of acidophil cells in mitosis at various times of the reproductive cycle suggest that the pace of mitotic activity varies independently in these two cell types with changing physiological conditions. There is a contrast between the unmated control animals, where mitotic activity is mostly confined to the somatotrophs, and the pregnant does where it is found predominantly in the prolactin cells. Unfortunately the situation is obscure when cell division is maximal in early lactation because of the high proportion of dividing nongranular, and therefore unidentifiable, cells; the mitotic rate may then be high in both types of acidophil cells. Few animals at later stages of lactation were examined but the figures available suggest that proliferative activity diminishes more rapidly in the prolactin cells than in the somatotrophs.

A second type of erythrosinophil cell, containing very fine granules, and called the epsilon or ACrH cell (Racadot \& Herlant, 1960; Herlant, 1965) has not been identified in the rabbit adenohypophysis. These cells are restricted to the antero-lateral region of the gland in the cat, sheep and pig and are far outnumbered by the coarse-granuled prolactin cells. If similar cells are present in the rabbit gland they would have been classed as non-granular cells in the present work; moreover, few mitoses were seen in the anterior region which, in the rabbit, is largely occupied by the zona tuberalis.

Meites \& Turner (1942) reported that the prolactin content of the rabbit pituitary rises at the end of pregnancy, is at maximal levels during the first 10 days of lactation and then declines gradually. Our data show that cell proliferation in the pituitary follows a similar pattern. Hunt (1949) found that in the rat also the period of greatest mitotic activity, i.e. the first 3 days of lactation, coincided with the highest prolactin levels.

The marked variation of the mitotic rate in the pituitaries of individual rabbits in groups of comparable reproductive status recorded here is in agreement with findings in the rat (Hunt, 1949; Hunt \& Hunt, 1966; Racadot, 1955). Hunt \& Hunt consider that there are periods of rising and falling proliferative activity in any one animal, with a peak or platform between, and that animals in a comparable physiological state may be killed at different stages of this mitotic cycle. This could explain the most discordant results in two groups of rabbits (the five unmated, pubertal animals and the three lactating animals killed 9 to 16 days post partum) where in one animal of each group, presumably killed during a peak period of mitotic activity, the rate is far higher than in the other members of the group.

Swann (1957, 1958), Abercrombie (1957) and Goss (1964), in discussing the nature of growth regulating factors, point out that both growth and secretory 
activity in a gland are stimulated by functional demand. In the adenohypophysis, secretory activity appears to be controlled by a feedback mechanism, operating through the hypothalamus. In the case of the two classes of acidophil cells, the regulators may be the demands for prolactin and somatotrophin respectively. There is evidence suggesting that, in pregnancy and lactation, oestrogen (Meites \& Nicoll, 1966), somatotrophin (Grosvenor \& Turner, 1959), and suckling (Tindal, 1967; Grosvenor, Krulich \& McCann, 1968) may also be involved in some species in the regulation of the synthesis and release of prolactin. For example, the release and/or the synthesis of the prolactininhibiting factor of the hypothalamus appears to be suppressed by oestrogen and by suckling (Ratner \& Meites, 1964; Grosvenor, Mena, Dhariwal \& McCann, 1967). In addition, both oestrogen and somatotrophin may have a direct mitogenic action on the adenohypophysial cells. The latter hormone has been shown to increase the rate of cell division in a wide range of tissues, but its effect on the pituitary does not appear to have been investigated (Bullough, 1955; Swann, 1958). The stimulating effect of oestrogen on mitosis in the rat and mouse pituitary, however, has been established by a number of studies (Halpern \& D'Amour, 1936; Wolfe \& Chadwick, 1936; Hunt, 1947a, b, 1949; Kerr, 1943). The oestrogen level is high at times during pregnancy in the rabbit (Beerstecher, 1942) and the occurrence of a post partum oestrus indicates that it is raised about the time of parturition. The mitotic rate in late pregnancy and after parturition may therefore be influenced by the level of oestrogen both by a direct mitogenic action and indirectly by the suppression of the hypothalamic prolactin-inhibiting factor.

According to the classification by Abercrombie (1957) of the types of new tissue formation following various stimulus mechanisms, the mitotic episodes in the hypophysis during pregnancy and lactation would appear to be of the compensatory kind and controlled by the systemic concentration of hormones. Wright (1958) has suggested that regulators of this sort, although basically having the nature of work-stimuli which control the mean secretory activity per secretory cell (see also Abercrombie, 1957) may, in more extreme situations, evoke bursts of mitotic activity and thus initiate the formation of new tissue.

\section{ACKNOWLEDGMENTS}

We are most grateful to the Medical Research Council for a personal grant to one of us (M.A.) during the course of this work, and to Mr P. Collingbourne for his technical assistance.

\section{REFERENGES}

Aвercrombie, M. (1957) Localized formation of new tissue in an adult mammal. Symp. Soc. exp. Biol. $\mathrm{XI}, 235$.

Allanson, M., Cameron, E. \& Foster, C. L. (1966) Observations on the acidophil cells of the adenohypophysis of pregnant and lactating rabbits. F. Reprod. Fert. 12, 319.

Allanson, M., Foster, C. L. \& Menzies, G. (1959) Some observations on the cytology of the adenohypophysis of the non-parous female rabbit. Q. Fl microsc. Sci. 100, 463.

Allanson, M. \& PARkes, A. S. (1966) Cytological and functional reactions of the hypophysis to gonadal hormones. In: Marshall's Physiology of Reproduction, 3rd edn., Vol. III, chap. 26. Ed. A. S. Parkes. Longmans Green, London. 
Altmann, G. G. \& Enesco, M. (1967) Cell number as a measure of distribution and renewal of epithelial cells in the small intestine of growing and adult rats. An. F. Anat. 121, 319.

BEERSTECHER, E. (1942) Variations in estrogen content of urine of female rabbits. Endocrinology, 31, 479.

Brookes, L. D. (1968) A stain for differentiating two types of acidophil cells in the rat pituitary. Stain Technol. 43, 41 .

Bullough, W. S. (1955) Hormones and mitotic activity. Vitams Horm. 13, 261.

Cameron, E., Foster, C. L. \& Allanson, M. (1966) The mucoid cells of the adenohypophysis of the rabbit during pregnancy and lactation. $\mathcal{F}$. Reprod. Fert. 12, 199.

CARTER, S. B. (1953) The influence of oestrone on the division of cells. F. Endocr. 9, 19.

Dawson, A. B. (1937) The relationships of the epithelial components of the pituitary gland of the rabbit and cat. Anat. Rec. 69, 471 .

GePts, W. (1954) Etude morphologique de l'hypophyse de la lapine au cours du post-partum. C.r. Séanc. Soc. Biol. 148, 189.

Goss, J. (1964) Adaptive growth. Academic Press, London.

Grosvenor, G. E., KrUlich, L. \& McGanN, S. M. (1968) Depletion of pituitary concentration of growth hormone as a result of suckling in the lactating rat. Endocrinology, 82, 617.

Grosvenor, G. E., Mena, F., Dhariwal, A. P. S. \& MaGann, S. M. (1967) Reduction of milk secretion by prolactin-inhibiting factor: further evidence that exteroceptive stimuli can release pituitary prolactin in rats. Endocrinology, 81, 1021

Grosvenor, C. E. \& Turner, G. W. (1959) Lactogenic requirements for milk secretion in intact lactating rats. Proc. Soc. exp. Biol. Med. 101, 699.

HALPERN, S. R. \& D'Amour, F. E. (1936). Studies on the gonad-hypophyseal complex in estrin-injected rats. Am. F. Physiol. 115, 229.

HerLant, M. (1964) The cells of the adenohypophysis and their functional significance. Int. Rev. Cytol. $17,299$.

Herlant, M. (1965) Present state of knowledge concerning the cytology of the anterior lobe of the hypophysis. Proc. 2nd Int. Congr. Endocrinology, London, 1964. Excerpta med. Int. Congr. Series No. 83, p. 468.

HUNT, T. E. (1943) Mitotic activity in the anterior hypophysis of female rats of different age groups and at different times of the day. Endocrinology, 32, 334 .

Hunt, T. E. (1947a) Mitotic activity in the hypophysis of the pregnant rat after injections of oestrogen. Proc. Soc. exp. Biol. Med. 64, 185.

Hunt, T. E. (1947b) Mitotic activity in the anterior hypophysis of ovariectomized rats after injections of oestrogens. Anat. Rec. 97, 127.

Hunt, T. E. (1949) Mitotic activity in the hypophysis of the rat during pregnancy and lactation. Anat. Rec. 105, 361 .

HUNr, T. E. \& HuNT, E. A. (1966) A radiographic study of the proliferative activity of adrenocortical and hypophyseal cells of the rat at different periods of the estrous cycle. Anat. Rec. 156, 361 .

Kerr, T. (1943) Mitotic activity in the female mouse pituitary. F. exp. Biol. 20, 74.

LADMAN, A. J. (1954) Mitotic activity in the anterior pituitary of the pregnant mouse. Anat. Rec. 120, 395.

Leblond, C. P. \& Walker, B. E. (1956) Renewal of cell populations. Physiol. Rev. 36, 255.

Mertes, J. \& Nicoll, G. S. (1966) Adenohypophysis: prolactin. A. Rev. Physiol. 28, 57.

Meites, J. \& TURNer, G. W. (1942) Studies concerning the mechanism controlling the initiation of lactation at parturition. IV. Influence of suckling on the lactogen content of the pituitary of post partum rabbits. Endocrinology, 31, 340.

Pomerat, G. R. (1941) Mitotic activity in the pituitary of the male white rat following castration. Am. 7. Anat. 69, 89.

RACADOT, J. (1955) La reproduction mitotique des cellules pituitaires alpha au cours du post partum chez le cobaye et le rat. C.r. Ass. Anat. 87, 1094.

Racadot, J. \& Herlant, M. (1960) L'action de l'amphénone sur l'hypophyse du chat impubère. Annls Endocr. 21, 828.

Ratner, A. \& Meites, J. (1964) Depletion of prolactin-inhibiting activity of rat hypothalamus by estradiol or suckling stimulus. Endocrinology, 75, 377

Swann, M. M. (1957) The control of cell division: A review. I. General mechanisms. Cancer Res. 17, 727.

Swann, M. M. (1958) The control of cell division: A review. II. Special mechanisms. Cancer Res. 18, 1118.

TINDAL, J. S. (1967) Studies on the neuroendocrine control of lactation. In: Reproduction in the Female Mammal. Eds. G. E. Lamming and E. C. Amoroso. Butterworths, London.

Wolfe, J. M. \& CHADwick, C. S. (1936) Quantitative studies on the structural changes induced in the anterior hypophysis by injections of oestrin. Endocrinology, 20, 503.

WRIGHT, G. PAYLING (1958) An introduction to pathology, 3rd edn, chap. XXI. Longmans Green, London. 